\title{
W „Drohobyczach” - wokół zbioru poetyckiego Serhija Żadana
}

Dlaczego w XXI wieku ukraiński poeta, urodzony w roku 1974 na dalekim wschodzie kraju, zatytułował swój zbiór wierszy z lat 2014-2016 Drohobycz...? Odpowiedź nie jest oczywista, ponieważ nie jest nią sam biograficzny fakt pierwszego spotkania z miejscem, do którego doszło właśnie w 2014 roku, czy kolejne - już regularne - w nim odwiedziny. Nie jest nią także (oczywista, zdawałoby się) interakcja artysty z miastem-symbolem, miastem-mitem, która „powinna” zyskać swój tekstowy kształt. Wiele wyjaśnia wprowadzenie, zatytułowane Drohobycz i okolice, będące zarówno fragmentem niejako autonomicznym, jak i ściśle splecionym z zawartością zbioru autokomentarzem. Serhij Żadan określił w tym wstępnym prozatorskim eseju pierwszą przyczynę swojej fascynacji:

Drohobycz to miasto, które było miastem, kiedy miast prawie nie było. Ma ono miejską zabudowę. Czyli chaotyczną i nieuporządkowaną. Czyli najwygodniejszą dla mieszkańców. Czyli taką, która pozwala zabłądzić między dwoma ulicami i trzema kościołami. Bo jeśli w mieście nie można zabłądzić - no to w ogóle nie jest to miasto ${ }^{1}$.

${ }^{1}$ S. Żadan: Drohobycz. Ksiegga wierszy wybranych (2014-2016). Przeł. J. PodsiadŁo. Warszawa 2018, s. 8-9. Dalsze cytaty podaję według tego wydania i opatruję skrótem D oraz numerem strony. 
Drohobycz różni się od miast wschodniej Ukrainy² i już pierwsza wizyta odsłoniła pisarzowi jego odmienność ${ }^{3}$. Nie bez znaczenia był też moment historyczny spotkania: czas kolejnej politycznej zawieruchy niszczącej spokój i nadzieje na przyszłość mieszkańców kraju ${ }^{4}$, sprawiającej jednocześnie, że coraz wyraźniejsze stawały się cienie przeszłości.

Drohobycz okazał się miastem wypełnionym przez wszechobecne zjawy, albowiem - jak wyjaśnił Żadan - na „miejsca zbrodni” ciągną nie tylko zbrodniarze, ale i ofiary. Nadto miejsca takie mają również szczególną moc przyciągania żyjących, a to ze względu na swój niezwykły status ontologiczny: „Jakoś łamie się tam struktura przestrzeni, i struktura czasu tak samo, i możesz tam zastygnąć, czując, jak historia podąża dalej, obchodząc cię, omijając, nieświadoma twojej obecności” (D, 9). Wizyta w takim miejscu uświadomić może dogłębnie i znikomość ludzkiego losu, i kruchość egzystencji.

W powszechnym wyobrażeniu Drohobycz jest nade wszystko miastem Brunona Schulza ${ }^{5}$ - to jego stała „obecność” wyznacza ścieżki poznawania/ czytania miejsca. Pierwsze zdania tomu brzmią: „Cień Schulza przemknął zaraz, jak tylko zapadł zmrok. Letnie noce nie skąpią cieni, więc nic dziwnego, że pojawił się wśród nich i cień Schulza”, a pierwszy akapit kończy konstatacja: „W Drohobyczu wszyscy mieliśmy jednego i tego samego znajomego. Nazywał się Schulz. Spróbuj go sobie przypomnieć. Albo wyobrazić” (D, 7). Cytaty z dzieł autora Sklepów cynamonowych służą za szczególny przewodnik po mieście, także tym współczesnym, a pamięć o życiu i śmierci pisarza przesłania historię cywilizacyjnego rozwoju Drohobycza.

Inny twórca ukraiński, Jurij Andruchowycz, w swoim Leksykonie miast intymnych..., w rozdziale Drohobycz 2007, na początku tekstu odtwarza w zarysie

2 Żadan przekonuje, że mieszkańcy wschodniej Ukrainy inaczej postrzegają „miejskość”: „[...] dla nas miasto to kupa wypaczonego przez ludzki geniusz żelazobetonu, miasto zaczyna się dla nas tam, gdzie w procesie produkcji niszczy się zdrowie od stu tysięcy ludzi wzwyż, wszystko inne to nie jest tak naprawdę miasto, tylko wieś [...] A co to takiego typ miejski? Infrastruktura i branża niewyszukanych rozrywek" (D, 8).

${ }^{3}$ Żadan przyjechał do Drohobycza na zaproszenie organizatorów V Międzynarodowego Festiwalu Brunona Schulza w czerwcu 2014 r.

${ }^{4}$ Paweł Próchniak przypomina w nocie końcowej: „To właśnie te zimne, deszczowe dni pierwszego pobytu - w kilka miesięcy po rosyjskiej aneksji Krymu i niedługo po dramatycznych wydarzeniach w wielu miastach Ukrainy - pojawiają się w eseju Drohobycz i okolice" (D, 104).

${ }^{5}$ Zob. J. Jarzęвski: Miasto Schulza. W: Tenże: Prowincja Centrum. Przypisy do Schulza. Kraków 2005. 
dzieje okolicy. Dostrzega inne „cienie” i przekonuje, że „zbliżanie się do Drohobycza wywołuje zjawy jego naftowego rozkwitu". Ale i on ostatecznie pisze o Schulzu oraz jego skomplikowanych, nieoczywistych relacjach z rodzinnym miastem i przypomina moment śmierci:

Nikt inny nie umierał z tak wyrazistą dokładnością topograficzną, z tak przenikliwym efektem obecności w swoim mieście i miejscu. Nikt inny nie leżał, już będąc trupem, w samym jego centrum, na rogu ulic Mickiewicza i Czackiego, przez kilka dni i nocy, póki jego niewielkiego i ptasiego, zesztywniałego na listopadowym chłodzie ciała nie ciśnięto do wspólnego żydowskiego dołu, na samo dno innego, podziemnego Drohobycza ${ }^{7}$.

Podziemne miasto pełne jest bezimiennych grobów, przestrzeń chtoniczną zasiedliły zjawy i upiory przeszłości - stamtąd wychodzą na świat i przypominają o swym istnieniu.

Poznawanie Drohobycza dokonuje się dziś z reguły przez filtr nałożony przez Schulza i to zarówno przez jego teksty, jak i tragicznie zakończoną biografię. Wcześniej miasto określano jako „zagłębie soli lub ropy naftowej”, „miasto cebularzy", „wylęgarnię biedoty", a w okresie międzywojennym bywało nieraz areną konfliktów klasowych, religijnych i etnicznych. Później jednak stało się widomym znakiem Zagłady, a zatem zyskało podwójny status ontologiczny: istniejącego w pamięci kulturowej powidoku sprzed katastrofy oraz współczesnych urbanistycznych pozostałości po mieście (zespolenia namacalnych fragmentów zabudowy, rozmaitych resztek, śladów, jak i pustki po tych, którzy odeszli). Miejsca, gdzie w przeszłości rozgrywały się ważne zdarzenia, z reguły trwają, choć $\mathrm{w}$ odmienionym przez destrukcyjne siły Historii kształcie. $Z$ powierzchni ziemi znika ich pierwotna postać, choć trwa pamięć o utraconej substancji. W szczególny sposób problem ten łączy się z miejscami związanymi z Zagładą, w których pamięć poddawana jest ciśnieniu najrozmaitszych, nieraz wykluczających się i zwalczających dyskursów.

Niewyrażalne w swej istocie dzieje Holokaustu rozgrywały się w przestrzeni, w której dawne miejsca kaźni teraz zmieniły swój charakter. Pusta łąka, las, wchłaniane przez naturę pozostałości budynków lub - odwrotnie - powstająca na gruzach dawnego świata nowa zabudowa miejska (gdy przestrzeń została przejęta przez nowych właścicieli) to przekształcenia wspomagające zacieranie pamięci o tragedii i jej niepojętym wymiarze. Prowadzić mogą nawet do

${ }^{6}$ J. Andruchowycz: Drohobycz 2007. W: TenżE: Leksykon miast intymnych. Swobodny podręcznik do geopoetyki i kosmopolityki. Przeł. K. KotyńsKa. Wołowiec 2014, s. 94.

7 Tamże, s. 96.

${ }^{8}$ A. Cемbiк: Drohobycz, Drohobycz. W: Polskie czytanie Wschodu. Kultura - autobiografia - edukacja. Red. M. Kwiatkowska-Ratajczak, B. Przymusząa. Poznań 2018, s. 87. Cembik przywołuje m.in. krytyczną wizję miasta w relacji z podróży po Polsce Aleksandra Döblina z 1924 r. (tamże, s. 69-70). 
obrazoburczego, a zarazem konstruującego podwaliny publicznej niepamięci twierdzenia, że Wydarzenie „nie miało miejsca”, czego skutkiem staje się swoiste delegalizowanie i usuwanie $\mathrm{z}$ oficjalnych dyskursów całych (bolesnych, niewygodnych, „niestosownych”) obszarów pamięci o przeszłości ${ }^{9}$. Powojenne zmiany granic ułatwiały wymazywanie śladów realności startej z powierzchni ziemi.

Zacieranie, przekształcanie pamięci było również zadaniem literatury. Andrzej Chciuk, polski emigrant $\mathrm{z}$ antypodów, $\mathrm{w}$ prozie wspomnieniowej zatytułowanej Atlantyda... z 1969 roku wykreował nostalgiczną wizję „Wielkiego Księstwa Bałaku”, przestrzeni swej szczęśliwej młodości. Pisarz tworzył iluzję bezpośredniości przedstawianych obrazów - spisywanych, by ukazały się oczom czytelnika „tak, jak spływają z pióra”. Narrator przekonywał bowiem, że „nie ma tu innej kompozycji niż miłość i rozrzewnienie, niż prawda wspomnienia, jakie boli i cieszy zarazem i rządzi się swymi prawami pamięci, wszystko upiększającej nieco, ale i wszystko rozumiejącej coraz lepiej”"10. Arkadiusz Bagłajewski wyjaśniał istotę tego twórczego procesu:

Swoisty paradoks relacji Chciuka z jego miejscem intymnym polega na tym, że Drohobycz mógł stać się „okolicą” po latach, po głęboko przeżytym doświadczeniu utraty. Pod australijskim skwarnym niebem odżywa galicyjskie miasteczko i zostaje ono nasycone znaczeniami, które przecież w codziennym życiu młodego człowieka nie odznaczały się aż taką barwą, klimatem, intensywnością przeżycia ${ }^{11}$.

Zamieszczony w Atlantydzie... oraz Ziemi księżycowej (1972) zestaw wspomnień, marzeń oraz kompensacyjnych wizji przekształcił się w spójny „drohobycki arras”, tkany na potrzeby podobnych do autora rozbitków, polskich wygnańców.

Inny zamysł przyświecał Henrykowi Grynbergowi, który pod koniec lat 90. XX wieku wydał zbiór opowiadań-relacji świadków Drohobycz, Drohobycz. Najistotniejszym celem tomu stała się rekonstrukcja skali zniszczeń, jakie dokonały się na wschodnich terenach Polski, scalenie obrazów Zagłady, która pochłonęła żydowskich mieszkańców miasta - spisanie dziejów ostatecznej katastrofy przeczuwanej przez wielu, zanim jeszcze nadeszła. Narrator tytułowego opowiadania przekonywał: „Ja czułem niebezpieczeństwo od dawna. Zwłaszcza gdy zaczęli przyjeżdżać uciekinierzy"12. Niepokojące historie uchodźców były dla niego znakiem zbliżającej się tragedii: „Ja słuchałem i ja wierzyłem, i opowiadałem w domu, a tam, on wariat, mówili. A ja się bałem, ja wiedziałem"13.

9 Zob. A. Krynicka: Heterotopia Drohobycz. Dostępne w Internecie: http:/www.nowakry tyka.pl/spip.php?article418 [data dostępu: 02.04.2016].

10 A. Chсіuк: Atlantyda. Opowieść o Wielkim Księstwie Bałaku. Warszawa 1989, s. 19.

${ }^{11}$ A. Bageajewski: Andrzej Chciuk - pisarz (z) Drohobycza. „Ruch Literacki” 2014, z. 1, s. 89.

${ }^{12}$ H. Grynberg: Drohobycz, Drohobycz. Warszawa 1997, s. 20.

13 Tamże, s. 21. 
Opisy miasta przekształciły się w opowieść o losach mieszkańców, z których większość nie dożyła końca wojny. Tym, którzy przetrwali, na wiele lat odmówiono prawa głosu. Narrator stwierdził z gorzkim sarkazmem:

Chciuk mieszkał po wojnie w Australii i publikował niewinne nostalgiczne wspomnienia z Drohobycza. A żydowscy rozbitkowie kupowali to jak ryby na szabas. I ze wzruszeniem gościli go w Izraelu. Uch, Żydzi to taki głupi naród! ${ }^{14}$

Historie z utraconej drohobyckiej okolicy, a raczej ich tekstowy kształt, stawały się tym samym przedmiotem nierozwiązywalnego sporu o autentyzm świadectwa. Na marginesie dodać można, że zarówno w Atlantydzie... Chciuka, jak i w opowieści narratora Grynberga Schulz pozostaje nauczycielem, osobą zapamiętaną przez młodych ludzi przez pryzmat codziennych szkolnych spotkańn ${ }^{15}$ oraz późniejszych okupacyjnych doświadczeń. Odheroizowana na wiele sposobów postać „belfra” jest jednocześnie postacią, której nie można zapomnieć, nieusuwalnym składnikiem wspomnień o mieście.

Życiorys Schulza kondensuje w sobie losy mieszkańców miasta, ich czas miniony, a jednak stale obecny. Zarówno poprzez jego dzieło, jak i pozostałości dawnej substancji miasta (rozpoznawane jako zarazem "realne” i "tekstowe”) przeszłość jawi się jako heterogeniczny zestaw „śladów” i „odcisków” pamięci. Maria Delaperrière tak definiowała najistotniejsze różnice pomiędzy nimi:

[...] ślad jest pojęciem metafizycznym, zaświadcza o symbolicznym trwaniu, jest abstrakcyjną reprezentacją tego, co nieobecne, natomiast odcisk jest znakiem konkretnym, metonimicznym, szczegółem materialnym. Symbolika śladu uruchamia wyobraźnię i tym samym uobecnia przeszłość, podczas gdy odcisk jest konkretem, szczegółem, który ujawnia przepaść między przeszłością i teraźniejszością, i tym samym jest definitywnym zaprzeczeniem ciągłości czasowej $^{16}$.

W Drohobyczu egzystencja Schulza traktowana jako tekst kultury oraz nierozłączna z nim spuścizna artystyczna pozostają zarówno „śladem”, jak i „odciskiem” owej heterogenicznej przeszłości. Niezwykła siła literatury (śladu minionego) uruchamia wyobraźnię, uobecnia utracone miasto, natomiast wspólnotowa wiedza o przyczynach i okolicznościach śmierci staje się odciskiem,

${ }^{14}$ Tamże, s. 60. Grynberg oskarżył Chciuka o czynny antysemityzm - ważniejszy jednak wydaje się fakt, że owo oskarżenie było dla Grynberga równoznaczne z nieodwołalną odmową prawa do pisania (czegokolwiek) o Drohobyczu dla każdego twórcy pomijającego niewygodne aspekty przeszłości.

${ }^{15}$ Zob. W. Budzyński: Uczniowie Schulza. Warszawa 2011.

${ }^{16}$ M. Delaperrière: Miejsca pamięci czy pamięć miejsc? Kilka refleksji na temat uobecniania przeszłości w literaturze wspótczesnej. W: Kulturowa historia literatury. Red. A. ŁeBкowsKa, W. Bolecki. Warszawa 2015, s. 168. 
swoiście „namacalnym” konkretem odsłaniającym przepaść między minionym a obecnym.

W zbiorze poetyckim Żadana ukazywane, lecz odrealnione na najrozmaitsze sposoby miejsca, $\mathrm{w}$ dodatku zaludnione istotami o niepewnym statusie ontycznym (podobnie jak „wzorcowy” dla nich Drohobycz i jego cienie), nie są tłem czy scenerią zdarzeń - stają się wyrazistym znakiem (re)konstruowanej przez podmiot tożsamości. Usuwana ze zbiorowej świadomości bolesna przeszłość wraca w odmienionej postaci, by umożliwić mówienie o teraźniejszości. Przemysław Czapliński w artykule Źle przemieszani tak dookreślał ów proces: „Szukanie pozostałości dawnych habitusów w tożsamości nowej - to właśnie zadanie z zakresu historiografii znikania. Kiedy posuwamy się w głąb znikania, uprawnione staje się pytanie, jak istnieje to, co znika. Odpowiedź brzmi: nie w pełni" ${ }^{\prime 17}$. Jednak rekonstruowanie owej niepełnej, widmowej obecności minionego w istotny sposób kształtuje pojmowanie dzisiejszego świata.

Postacie $\mathrm{z}$ przeszłości istnieć mogą $\mathrm{w}$ heterogenicznie postrzeganej teraźniejszości nie tylko jako uobecniane wspomnienie. Powołane do życia przez literaturę, a bytujące w strefie "pomiędzy" - ułudą a rzeczywistością, fantazją i pamięcią, fikcją i śladem realnego - zaświadczają przede wszystkim o poszukiwaniu odmiennej niż powszechnie akceptowana drogi ku samopoznaniu, a jednocześnie pozostają znakiem nieodwołalnie utraconych światów. Podmiot zbioru wierszy Żadana również przynależy do obu rzeczywistości rozdzielonych czasem - wbrew destrukcyjnym, ,żarłocznym” zakusom teraźniejszości, w której musi egzystować, opowiada się za wypełnieniem obowiązku rekonstruowania widmowego miejsca, jakim jest dziś Drohobycz.

Przebywanie w "przestrzeni zbrodni” zmienia postrzeganie siebie i własnego miejsca na ziemi. Pamięć o przeszłości i świadomość niepewnej teraźniejszości budzą żal, który domaga się artykulacji - zarówno istnienie, jak i unicestwienie rzeczywistości zachowanej jedynie w literackich tekstach, ułomnej ludzkiej pamięci, na wyblakłych fotografiach, zetlałych mapach uświadamia nade wszystko, jak bardzo niepewna jest przyszłość: jednostki, wspólnoty, narodu, ludzkości. Pamięć o miejscach, ich skomplikowanej, splątanej, „przemieszanej” historii nakazuje namysł nad kwestiami tożsamości (jednostkowej i zbiorowej) oraz utrudnia wybór najprostszych, sankcjonowanych ideologicznie czy politycznie odpowiedzi i rozwiązań.

Proza Schulza przechowuje artystyczny wzorzec subiektywnego postrzegania i rekonstruowania otaczającej przestrzeni. Piotr Paziński w poświęconym Sklepom cynamonowym eseju Rzeczywistość poprzecierana tak określił zadania wyznaczone w niej czytelnikom: „Cokolwiek znajduje się za obrazem, po drugiej stronie matowej szybki, przez którą do wnętrza kalejdoskopu wpada promień

17 P. Czapliński: Źle przemieszani. „Poznańskie Studia Polonistyczne. Seria Literacka” 2013, nr 22 (42), s. 98. 
światła - nam pozostaje podglądanie ruchu kolorowych szkiełek zwielokrotnionych lusterkami"18. Nadto każda lektura pozostaje lekturą pierwszą i jednokrotną - nie jest też możliwe ustalenie jednej wykładni tekstu. Za każdym razem czytać będziemy „nowy” utwór: „Formy, jakie ujrzymy, nigdy drugi raz się nie powtórzą, chociaż ilość elementów, odruchów kolorowego szkła jest ograniczona" ${ }^{\prime 19}$. Jednak właśnie tekst pozostający w ciągłym ruchu paradoksalnie przeciwstawia się procesom erozji czy znikania, zarówno miejsc, jak i sensów. To, co „za szybką", nie zastyga też w jednym kształcie, gotowym do użycia (a zatem i zużycia) dla doraźnych celów.

$\mathrm{W}$ ostatecznym rozrachunku nieobecność przejawia się jako utrata i brak, ale istnieje także jako wielorako przedstawiana, ukazywana, wyodrębniana w swym niepewnym statusie widmowa (nie)obecność. Tak pojmowana nieobecność - jako wyzwanie i zobowiązanie - definiuje i przestrzeń, i doświadczający jej zakrzywień oraz labiryntowych pułapek podmiot. Określa zarówno formy uobecnianej literacko pamięci, jak i tożsamość opowiadającego. Dominick LaCapra w tekście Trauma, nieobecność, utrata stwierdził: „Uznając, afirmując czy przepracowując nieobecność jako nieobecność, należy rozpoznać zarówno wątpliwą naturę ostatecznych rozwiązań, jak też niezbędnego lęku, którego nie sposób wyeliminować $\mathrm{z} » j \mathrm{a}$ « czy projektować na innych" ${ }^{20}$. Tak rozumiana nieobecność jest w swej istocie ambiwalentna - wywołuje lęk, ale również inspiruje, a nawet ekscytuje, wchodzi także w złożoną i determinującą obie strony interakcję z obecnością ${ }^{21}$.

Inspirująca i ekscytująca (nie)obecność Schulza oraz towarzyszących mu cieni determinuje współczesne postrzeganie Drohobycza. Istnieją w obrębie swej dawnej przestrzeni - na przekór wszelkim działaniom prowadzącym do zatarcia jej palimpsestowej historii. Ambiwalentnie postrzegana kategoria "miejsca pamięci" nie może okazać się w przypadku tego miasta przydatna, nawet jeśli weźmie się pod uwagę oczyszczoną z ideologicznych (politycznych, nacjocentrycznych) uwarunkowań istotę tego kulturowego projektu. W artykule Romy Sendyki, zatytułowanym Miejsca pamięci - lektury krytyczne, koncept Pierre’a Nory prezentuje się ostatecznie jako różnorodnie rozwijana i doprecyzowywana koncepcja intelektualna, a jej ośrodkiem jest „niefalsyfikowane pojęcie pierwotne, wariant mitu, w którym nie ma miejsca na dyskusje, pozostaje jedynie

${ }^{18}$ P. PAziński: Rzeczywistość poprzecierana. W: TenżE: Rzeczywistość poprzecierana. Kraków-Budapeszt 2015, s. 106.

${ }_{19}$ Tamże. Paziński podkreśla dalej: „Podobnie z językiem. Jego materia jest niby odwzorowaniem continuum, symboliczną reprezentacją »tamtej strony«, a więc jakiejś wyobrażonej jedności. Tyle, że tak się akurat składa, że Schulz pisze językiem wielości przedstawień i obrazów, które zostały mistrzowsko, ale tylko prowizorycznie scalone i zszyte jak patchwork" (tamże).

${ }^{20}$ D. LaCapra: Trauma, nieobecność, utrata. Przeł. K. Bojarska. W: Antologia studiów nad traumą. Red. T. Łysak. Kraków 2015, s. 77.

${ }^{21}$ Tamże. 
negocjowanie formy kultu"22. O Drohobyczu - teraz, gdy nie istnieje już realnie jego wieloetniczna wspólnota - można myśleć bez przymiotnika zwyczajowo określającego przypisanie miejsca jednej nacji. Dzieje się tak właśnie za sprawą Schulza, „znajomego nas wszystkich”23, i jego opowieści.

Oczywiście odzyskiwanie przeszłości w przesyconych nią miejscach odbywa się dziś z reguły za sprawą jednostkowego wysiłku - osobnej i osobistej decyzji uznania widmowego świata za realny i własny. Drohobycz stać się może tym samym miejscem współcześnie oswajanym i bliskim, a jednocześnie widomym znakiem katastrofy całego świata. Żadan rejestruje etapy swoich epistemologicznych poszukiwań, a jednocześnie chce zostać usłyszany i zrozumiany. Tomasz Bilczewski w artykule Trauma, translacja, transmisja $w$ perspektywie postpamięci... podkreślał wagę utworów literackich odsłaniających zranienia i obsesje związane z traumą przeszłości, a przekazywanych w drodze „międzypokoleniowej transmisji”. Zdaniem badacza „umożliwiają one wejście na nieuświadamiane lub słabo uświadamiane obszary indywidualnej i wspólnotowej historii”24. Mogą także pełnić funkcję „obiektu przekształcającego”, czyli „swoistego katalizatora pozwalającego w inny sposób spojrzeć na przeszłość, aby rozumieć i zmieniać swoje życie"25. Żadan z pewnością chciałby choćby zbliżyć się do Schulzowskiego wzorca nad-literatury i jej siły przemieniającej postrzeganie świata.

Drohobycz - miasto niezwykłe - nadal inspiruje. Ewa Rewers, pisząc o relacjach między sztuką i miastem, podkreśla, że dzisiaj nie pozostają już uwięzione w „lustrzanej metaforze”: „Sztuka dzisiaj nie jest zwierciadłem podsuwanym ulicom i placom, a miasto daje sztuce coś więcej niż kontekst i przestrzeń. Daje żywą, odnawialną metaforę współczesnego życia, świata, pamięci, porządku i chaosu zarazem"26. Literatura o mieście włącza się w proces diagnozowania ludzkiej kondycji w ponowoczesnej rzeczywistości, miasto jako mikrokosmos pozwala bowiem ukazywać reguły rządzące światem w szerszej skali, także tej globalnej. Żadan przekonywał, że zawsze „czyta” Drohobycz „literami sklepów cynamonowych, dziwacznymi i chimerycznymi zdaniami, z jakich zbudował swój świat Schulz" (D, 10). Z pewnością opowieści o mieście, połączone w polifoniczny, choć niepozbawiony dysonansów przekaz, nie mogą służyć tworzeniu tekstowego obrazu/odbicia realnego miasta i zdradzają swój niepewny episte-

${ }^{22}$ R. Sendyka: Miejsca pamięci - lektury krytyczne. W: Od pamięci biodziedzicznej do postpamięci. Red. T. Szostek, R. Sendyka, R. Nycz. Warszawa 2013, s. 212.

${ }^{23}$ Kontrowersyjny pozostaje $\mathrm{w}$ tym kontekście powszechnie znany fakt nie dość uzasadnionego (zarówno pod względem prawnym, jak i etycznym) przywłaszczenia rysunków Schulza $\mathrm{z}$ drohobyckiej willi Landaua przez władze izraelskie i umieszczenia ich w zbiorach Jad Waszem.

${ }^{24}$ T. BILCzewsKi: Trauma, translacja, transmisja w perspektywie postpamięci. Od literatury do epigenetyki. W: Od pamięci biodziedzicznej do postpamięci..., s. 62.

25 Tamże.

${ }^{26}$ E. Rewers: Wprowadzenie. W: Miasto w sztuce - sztuka miasta. Red. E. Rewers. Kraków 2010, s. 5 . 
mologicznie status - Żadan powie: „Oczywista jest błędność i niedoskonałość podobnego traktowania otaczającej rzeczywistości” (D, 10). Jednak z takiego czytania miasta rodzą się zdolność budowania nowych, głębszych relacji z innymi (również tymi uznawanymi za własne) miejscami na ziemi oraz wyzwolenie z narzucanych z zewnątrz reguł konstytuowania tożsamości.

Serhij Żadan określił we wprowadzeniu swój emocjonalny stan z czasów pierwszej wizyty w mieście i rozszerzył go na wspólnotę: „My byliśmy bardzo chorzy, smutni i rozdarci. A do tego pierwszy raz byliśmy w Drohobyczu" (D, 7). Miejsce inne niż te poznawane dotąd poruszyło jego wrażliwość, wyobraźnię i artystyczną aktywność. Drohobycz... Żadana to jego „prywatna historia przywiązania do miasta”, bardzo ważny rozdział "prywatnej geografii” (D, 13), pozbawiony wszelkich znamion ilustracyjności (podobnie jak zamieszczone w tomie pejzaże autorstwa Olgi Czyhryk) ${ }^{27}$. W końcowej nocie Paweł Próchniak podkreślił, że tu poeta „dotyka czegoś boleśnie ważnego dzisiaj, czegoś, co jest jak zastarzała, rdzewiejąca zadra, ale wydarza się tu i teraz - na Ukrainie, w Polsce i w Europie" (D, 104), a jego wiersze pozwalają szukać najrozmaitszych pokrewieństw między artystami zmagającymi się z okrucieństwem Historii ${ }^{28}$.

Doświadczenie egzystencjalne, zazwyczaj charakteryzujące się złożoną strukturą, konstytuuje się w ramach kulturowych wzorców. Jednostka, próbując je nazwać (a zatem zrozumieć), poszukuje gotowych reguł, odpowiedniego języka, obrazów, wzorców narracji, a tym samym kształtuje je w toku dopasowywania do istniejących formuł. Takie przeżycie, rozpoznawalne przez jednostkę właśnie jako doświadczenie, pozwala włączyć się „miękko” w pole pojedynczej egzystencji, jeśli kultura je rozpoznaje i sankcjonuje ${ }^{29}$. Nowość doświadczenia, które napotyka nieczytelność w sferze tradycji i nie znajduje dla siebie rozpoznawalnych sposobów przyswojenia, bywa na tyle mocna, że ów opór odebrany

${ }^{27} \mathrm{~W}$ zbiorze zamieszczono piętnaście grafik zamówionych specjalnie do tego tomu u artystki z Drohobycza. Obrazy przestrzeni utrzymane zostały przez Czyhryk konsekwentnie w konwencji surrealistyczno-onirycznej, wzbogaconej aurą specyficznej intymności, osobistej więzi $\mathrm{z}$ rodzinnym miastem.

${ }^{28}$ Próchniak wskazuje na zatarte więzi z Osipem Mandelsztamem: „[...] wspólny ton losu nowoczesnych artystów wydobywa i podtrzymuje gorzki, surowy ton ich życia i śmierci w morderczym uścisku totalitarnych reżimów. I mówi też coś istotnego o poruszeniach ich wyobraźni - wolnej i odważnej, wciąż żywej, bo wywiedzionej ze słowa i w nim utwierdzonej" (D, 105).

${ }^{29}$ Zob. T. Walas: Literatura (kultura) jako selekcja i projektowanie doświadczenia. W: Kulturowa teoria literatury 2. Poetyki, problematyki, interpretacje. Red. T. WALAs, R. Nycz. Kraków 2012, s. 280. 
zostaje jako bezsilność kultury. Doświadczenie może wówczas zostać usunięte z pola widzenia wspólnoty albo spowodować sproblematyzowanie języka i form kultury, ich znaczącą transformację ${ }^{30}$.

We współczesnych przestrzeniach komunikacji zachodzi konieczność przekładania, wyjaśniania podlegających nieustannym przemianom afektów na język emocji, zwłaszcza tych, które dotykają człowieka jako duchowo-cielesną jednię, zanurzoną w zbiorowym bycie. Artykulacja doświadczenia w literaturze odbywa się jednak z reguły przy znaczącym udziale wcześniejszych tekstów kultury. Żadan ma tę świadomość i wyraża zgodę na stan, kiedy literatura „wywraca cię na lewą stronę niczym rękawiczkę, wypełnia sobą twoje doświadczenie, podmienia je na siebie" (D, 13). Drohobyckie przeżycia, ufundowane na literackich wzorcach, dały impuls do spisywania doświadczeń o szerszym zasięgu. Codzienne obcowanie ze złem, z nieprawością, krzywdą słabszych, nieszczęściem odrzuconych i wykluczonych nie powinno stawać się wolnym od refleksji trwaniem na przekór przeciwnościom losu. Pozbawiona duchowych reakcji i interakcji egzystencja zmienia się w wegetację utrudniającą samopoznanie i podejmowanie prób zrozumienia świata. Pisanie okazuje się wówczas przede wszystkim swoistym antidotum konieczną autorefleksją oraz zadaniem zwróconym ku zewnętrznemu światu. Przeżywanie Miasta przekształciło się u Żadana w poezję zarazem zanurzoną w gorzkiej wiedzy o przeszłości i na wskroś współczesną.

Wiersze Serhija Żadana z lat 2014-2016 zostały ułożone w tryptyk. W rozdziale pierwszym twórca zamieścił poemat o utraconej miłości. Składający się $\mathrm{z}$ dziesięciu wyodrębnionych odsłon utwór jest przejmującym zapisem rozpadu uczuć, ukazanym na tle powszechnego rozkładu międzyludzkich więzi. Nie ma powrotu do minionego szczęścia - przypadkowe spotkanie uświadamia, jak dalece rozeszły się drogi dawnych kochanków:

Ona zauważa, że zmarszczki wokół oczu jeszcze mu się pogłębiły od niewyspania i smutku i palce mocniej pożółkły od tytoniu, i ubranie, to samo ubranie [...]

On zauważa jaskrawe buty do biegania

i że włosy ufarbowała sobie na kolor ognia można się oparzyć,

i usta, jakie ma usta - myśli on gorące, ogorzałe widać całuje się z kimś długo i szczęśliwie 
Miłość nie przetrwała, ponieważ miała niewielkie szanse $\mathrm{w}$ realiach postępującego zanikania wartości, atrofii sensów oraz destrukcji sacrum - można wprawdzie przeciwstawiać się degradacji bytu za pomocą poezji, nie jest ona jednak w stanie ocalać nawet „prywatnych” enklaw rzeczywistości.

Rozdział drugi to dziesięć wierszy „miejskich”, wyrastających z postrzegania miasta jako podstawowej przestrzeni egzystencji. Pozbawione tytułów teksty można czytać jako kalejdoskopowy przepływ miejskich widoków oraz ruch powiązanych z nim wizji utraty stabilnych reguł istnienia:

Nad głową klony kreślą wzór gotyku i ulewa krew ma zieloną, jakby była mątwą.

Tak gorzko dotykać czegoś, co znika od dotyku, gorzej jest tylko - nie móc dotknąć.

$$
\text { D, } 66
$$

Upał już od czerwca nas przypieka i żmije czają się pod poduszkami, chowają się w kuchniach i bibliotekach, wiją się za wierszami i za słownikami.

$$
\mathrm{D}, 45
$$

Ma piętnaście lat i sprzedaje kwiaty w dworcowej hali. Tlen za kopalnią jest słodki od jagód i ich zapachu.

Pociągi zamierają tu na chwilę i ruszają dalej.

Wojskowi jadą na Wschód, wojskowi jadą na Zachód.

$$
\mathrm{D}, 47
$$

Obrazy różnych miast (a może jednego Miasta) tworzą migotliwą projekcję niepochwytnych miejsc i z trudem zasiedlanych czy oswajanych przestrzeni, uzmysławiających nade wszystko kruchość jednostkowych wysiłków, by czynić owe miejsca własnymi, poznanymi, bezpiecznymi. Trudno oddać ich specyfikę, trudno się w nich odnaleźć. Tadeusz Sławek podkreślał ambiwalencję naszego doświadczania miejskiej rzeczywistości, spojrzenie na miasto z jednej strony z reguły zwykło bowiem ślizgać się jedynie po powierzchni rzeczy, z drugiej jednak może wspomagać proces ich jednostkowego konstruowania:

[...] miasto jest wielopojawieniowe; mimo tego samego nazewnictwa i tej samej topografii nie ma „jednego” miasta. W tej sytuacji nie wolno zadowolić się „jedną" wizją miasta, lecz należy postrzegać je tak, jakby znajdowało się dopiero „w drodze” do siebie, niegotowe, a jego pozornie najtrwalsze konstrukcje są $\mathrm{w}$ istocie najbardziej kruchymi i zwodniczymi ${ }^{31}$.

\footnotetext{
${ }^{31}$ T. SŁAWeK: Miasto. Próba zrozumienia. W: Miasto w sztuce - sztuka miasta..., s. 20.
} 
Miasto ukazywane przez wyraziście określone medium może okazać się przestrzenią podatną na akt uspójnienia - czy tym bardziej usensownienia odbywać się to musi jednak każdorazowo jako świadomy gest substancjalizacji miejsca, dokonywany w zwrotnej i wzajemnie przekształcającej relacji z podmiotem.

W rozdziale trzecim Drohobycza... - opatrzonym tytułem Dlaczego mnie nie ma $w$ sieciach społecznościowych - Żadan zamieścił dziesięć (znów) szczególnych, współczesnych portretów. Bohaterowie tworzą galerię najrozmaitszych typów. Tak rozpoczynają się opowieści zatytułowane Szabrownik, Player, Szpieg:

Życiorys nędzny

z takich życiorysów robi się poranne wiadomości

Jego stary zamarzł w grudniu, w pustym tramwaju.

Matka ma problemy z cukrem.

D, 84

Sasza, cichy pijak ezoteryk, poeta.

Całe lato przesiedział w mieście.

Kiedy zaczął się ostrzał - zdziwił się, zaczął oglądać wiadomości, potem przestał.

D, 88

Wołodia, lat 25, lekarz, psycholog, vloger, uczy zdrowego

stosunku do życia D, 94

Zwyczajni ludzie - z pozoru cwaniak, outsider i człowiek sukcesu - rzuceni w tryby historii okazują się jej ofiarami. Niezależnie od osobistych przymiotów czy słabości zmieniają się w coraz mocniej determinowane przez zewnętrzne siły istoty, pozbawione praw do samostanowienia.

Znany im świat rozpada się w przyspieszonym tempie. Zygmunt Ziątek przekonywał, iż historia i współczesność „pospołu złożyły się na to, że kategorie miejsca przestały być kategoriami pozytywnego, konstruktywnego myślenia, służącego odnajdywaniu czy budowaniu własnej tożsamości”32, a literatura zainteresowana miejscem ukazuje jego „niepewność, tymczasowość, dysharmonie sprzeczność lub wewnętrzną wrogość elementów składowych, wpisywanie się w owo miejsce przez walkę o jego charakter, a nie poprzez poznanie i przyjazne porozumienie"33. Dlatego właśnie tak bardzo potrzebna jest znajomość (czy

${ }^{32}$ Z. Ziąteк: Czas literatury miejsca. W: Gry o tożsamość w czasach wielkiej zmiany. Red. A. Werner, T. Żukowski. Warszawa 2013, s. 148.

${ }^{33}$ Tamże. 
nawet serdeczna więź) z cieniami przeszłości. Wspólnota polegająca na ciągłym, wciąż ponawianym doświadczaniu utraty pozostawać musi wspólnotą widmową, niedającą $\mathrm{w}$ istocie oparcia $\mathrm{w}$ przestrzeni egzystencjalnej - jej znamiona mogą jednak funkcjonować jako znaki rozpoznawcze w uniwersum tekstów kultury. Narracje skierowane ku widmom - jak pisał niegdyś Przemysław Czapliński mogą upatrywać „w tej fantomowej komunikacji szansy na zrozumienie nicości, która podczas Zagłady wdarła się do języka, życia społecznego i jednostkowej tożsamości"34. Pozwalają pochwycić skalę zniszczeń.

„Nicość” domaga się wysłowienia, nakazuje jednak szczególną ostrożność. Piotr Filipkowski, od lat zajmujący się problematyką historii mówionej, podkreślał, że wspólnotową historię fantazmatyczną warto utrzymywać w swoistym "niedomknięciu” przede wszystkim po to, by zachować czujność. Historia bowiem, zwłaszcza ta "duża”, staje się tworzywem - z jednej strony łatwym w użyciu, z drugiej bardzo niebezpiecznym:

[...] poznając ją, jesteśmy mądrzejsi o wiedzę faktograficzną, ale możemy być jednocześnie głupsi o sposób sklejania tych faktów w historię, ideologię, mitologię czy religię. Instytucje wymyślone do badania prawdy służą dziś budowaniu uproszczeń, mitów, zasilaniu narodowych fantazmatów. Eksperci z naukowymi tytułami często po prostu legitymizują aktualne emocje - może także własne ${ }^{35}$.

Żadan ma świadomość, jak niebezpieczne bywa „używanie” widm przeszłości, postuluje więc, by okazywać im szacunek, bez prób zawłaszczania, oraz zrozumienie, bez przymusu rozdzielania na „swoich” i „obcych”.

Przestrzeń wyznacza sposoby jej postrzegania i odtwarzania (wytwarzania) w tekście. Drohobycz, jak wiele innych miejsc w Europie zwanej środkową, to miasto pełne śladów po tych, którzy zginęli, których wymordowano i których próbowano wyrugować ze wspólnej pamięci. Jest to też miasto pełne pustek po zgładzonej z powierzchni ziemi wieloetnicznej, skłóconej społeczności. W tomie poetyckim Żadana odzyskiwanie przeszłości w jej niejednoznacznym kształcie może odbywać się poprzez literaturę. Poeta podsumowuje:

My - dzieci beznadziejnego dwudziestego stulecia, stulecia, w którym skończyła się historia, czyli skończyła się poezja, do końca swych dni pozostaniemy literaturocentryczni - odtwarzamy rzeczywistość z liter, wywodzimy jej zarysy ze znaków przestankowych, dla nas będzie naturalne mówić o geografii rymem.

D, 10

${ }^{34}$ P. Czapliński: Źle przemieszani..., s. 106-107.

${ }^{35}$ Ciagłość w zerwaniu. Rozmowa z Piotrem Filipкowsкim. „Krytyka Polityczna” 2018, nr 46, s. 154. 
Wielka literatura to drogowskaz, a zarazem jeden z ostatnich „punktów stałych" we współczesnym cywilizacyjnym chaosie oraz glejt pozwalający na prowadzenie samodzielnych poszukiwań, wyzwolonych $\mathrm{z}$ aktualnie obowiązujących reguł definiowania jednostek i zbiorowości.

Uważna obserwacja przestrzeni - jak przekonywała Ewa Rewers - uczy dostrzegania niepodważalnego faktu: równie ważne jak to, co obecne i zrealizowane, jest w niej to, co z różnych powodów nieobecne. Podkreślała przy tym:

Przestrzeń miejska, z jednej strony symultaniczna, wielowarstwowa i różnorodna, czyli na wiele sposobów zagęszczana, z drugiej strony przedstawia się jako obszar miejsc pustych, uskoków i nieciągłości, świat oglądany z perspektywy powstającej w stałym obcowaniu $\mathrm{z}$ miastem nie zaskakuje brakiem jedności, skłonnością do kumulowania sprzeczności. Aporetyczny charakter tej przestrzeni odnajduje bowiem swoje odpowiedniki we wszelkich sferach doświadczenia. Żyjemy w mieście-świecie wypełnionym przez aporie, w których nawarstwianiu bierzemy sami udział ${ }^{36}$.

Przestrzenie - i te wywiedzione z rzeczywistości czy odtwarzane z pamięci, i te nacechowane oraz przedstawiane metaforycznie, zrodzone na przecięciu jednostkowej wyobraźni i zbiorowych tradycji kultury - wpisują się w porządek nawarstwiania się aporii, są świadomie tworzonym odbiciem zatartych śladów i bolesnych pustek.

Żadan twierdził z pełnym przekonaniem, że pisząc o doświadczeniach współczesnych Ukraińców, pisał jednocześnie o Drohobyczu, o niebie ponad miastem, o śniegu dookoła, o jego parkach, o rzece, choć „nie dosłownie o tym, choć bez rozpoznawalnych toponimów i czytelnych nazwisk”, jednak nieodmiennie: „O całym tym miejskim tle, na jakim pojawiają się cienie i głosy, bez jakiego rozproszyłyby się po prostu w chłodnym powietrzu nocy” (D, 12). Tadeusz Sławek, rozważając relacje między przestrzenią miejską a zamieszkującym (odwiedzającym) ją człowiekiem, przekonywał z kolei, że miasto i jednostka jawią się dziś jako dwa współbieżne i niedokończone projekty. Najważniejszą rolę odgrywa dystans między zamierzeniem a spełnieniem, otwierający przestrzeń krytycznej refleksji. Badacz podkreślał: „Doświadczenie miasta zależy więc od miary naszego oddalenia od siebie"37. Drohobycz z pewnością „wspomógł” Żadana w poszukiwaniu dróg do zrozumienia siebie i świata oraz w umacnianiu świadomości, że to proces nieprowadzący ku ostatecznym zamknięciom, definicjom, podsumowaniom. Nie było - jak podkreślał pisarz - wcześniejszego zamysłu, by „przyjechać do tego dziwnego, cichego miasta zapolować na cienie

${ }^{36}$ E. Rewers: Post-polis. Wstęp do filozofii ponowoczesnego miasta. Kraków 2005, s. 306. Badaczka stwierdza także: „Narracje miejskie prowadzą w przeszłość, kształtują teraźniejszość i projektują przyszłość - jednocześnie" (tamże, s. 305).

37 T. SŁawek: Miasto. Próba zrozumienia..., s. 51-52. 
i głosy” (D, 12), jednak „śmiertelnie malownicza” i „pełna aluzji” przestrzeń domagała się słów, rytmu, poezji.

Coraz więcej wiemy o tym, w jaki sposób zmieniają nas miejsca naznaczone pamięcią Zagłady, jak wielki niosą ładunek zobowiązań i jak niezbywalnym stają się wyzwaniem. Lata 90. XX wieku można uznać za czas wstępnych działań „archeologicznych” w polskiej świadomości zbiorowej. Jak wspominał Janusz Makuch:

Zdaliśmy sobie sprawę, że żyjemy w świecie popiołów i zaczęliśmy zasypany świat odkrywać na nowo. Odkopywaliśmy jego fragmenty, próbowaliśmy składać w całość, gdy się zaś nie udawało - a tak było najczęściej - to na podstawie fragmentów budowaliśmy zmyślony obraz całości, na który projektowaliśmy własne marzenia i wizje ${ }^{38}$.

Dlatego polscy czytelnicy zrazu chętniej sięgali po Atlantydę... Chciuka, później dopiero zaczęli wczytywać się w opowiadania Grynberga z tomu Drohobycz, Drohobycz. Utracona przez Polaków „kresowa Arkadia” zaczęła zmieniać się w miejsce kaźni żydowskich współobywateli. Może kolejnym etapem - by "zobaczyć" dawnych mieszkańców miasta i zrozumieć, co mówią ich cienie powinien być powrót do Schulza?

Serhij Żadan, tworzący w ramach innej wspólnoty interpretacyjnej, przechodzącej odmienne etapy budowania zbiorowej tożsamości, w drugiej dekadzie XXI wieku, porównując dzisiejszą „rzeczywistość” z „wzorcem” Schulza, stwierdził jednoznacznie:

Wszystko jest właśnie tak, co do literki - nikt nic nie wie, nikt niczego nie odczytuje, ale czasu starcza na wszystko - i na zmianę dekoracji, i na odczuwanie tego miasta, i na przywiązanie do niego. Nic więcej nie trzeba. Nic więcej nie ma. Tylko przywiązanie. Tylko pisanie potem wierszy. Tylko konsolidująca się masa ziemi.

D, 13-14

Pisanie poezji - wywiedzione $\mathrm{z}$ doświadczenia miejsca, pamięci przeszłości i z umożliwiającej scalanie jednostkowych przeżyć literatury - nie ma już dziś wartości ocalającej w planie przeżyć zbiorowych. Wciąż jednak liryka, jako świadectwo duchowych poruszeń jednostki, pozwala odbiorcom wchodzić $\mathrm{w}$ rezonans z materią wierszy. Zrozumieć i odczuć mogą to również ci, którym nie dane było (jeszcze) zanurzyć się w heterotopicznej, palimpsestowej, zamordowanej, a jednak wciąż odzyskiwanej, przestrzeni Drohobycza.

38 J. Makuch: Od sztetla do Syjonu. „Tygodnik Powszechny” 2019, nr 1 (9): Polska żydowska (numer specjalny), s. 165. Makuch, jako współtwórca Festiwalu Kultury Żydowskiej, spotykał się z zarzutem tworzenia „żydowskiego Disneylandu” w martwych dekoracjach krakowskiego Kazimierza, jednak współczesne działania służące „rewitalizacji” dzielnicy postrzega przede wszystkim jako nacechowaną etycznie, choć wciąż chaotyczną próbę restytucji przeszłości. 


\section{Bibliografia}

AndRUCHOWyCz J.: Drohobycz 2007. W: J. AndRuchowycz: Leksykon miast intymnych. Swobodny podręcznik do geopoetyki i kosmopolityki. Przeł. K. KotrńsKa. Wołowiec 2014, s. 94-99.

BagŁajewski A.: Andrzej Chciuk - pisarz (z) Drohobycza. „Ruch Literacki” 2014, z. 1, s. 83-95.

Bilczewski T.: Trauma, translokacja, transmisja w perspektywie postpamięci. Od literatury do epigenetyki. W: Od pamięci biodziedzicznej do postpamięci. Red. T. Szostek, R. Sendyka, R. Nycz. Warszawa 2013, s. 40-62.

BudzyŃski W.: Uczniowie Schulza. Warszawa 2011.

Семвік A.: Drohobycz, Drohobycz. W: Polskie czytanie Wschodu. Kultura - autobiografia-edukacja. Red. M. Kwiatkowska-Ratajczak, B. PrzymuszaŁa. Poznań 2018, s. 69-90.

Chcıuк A.: Atlantyda. Opowieść o Wielkim Księstwie Bałaku. Warszawa 1989.

Ciagłość w zerwaniu. Rozmowa z Piotrem Filipkowskim. „Krytyka Polityczna” 2018, nr 46, s. $148-156$.

Czapliński P.: Źle przemieszani. „Poznańskie Studia Polonistyczne. Seria Literacka” 2013, nr 22 (42), s. 97-118.

Delaperrière M.: Miejsca pamięci czy pamięć miejsc? Kilka refleksji na temat uobecniania przeszłości w literaturze współczesnej. W: Kulturowa historia literatury. Red.

A. Łebkowska, W. Bolecki. Warszawa 2015, s. 161-172.

Grynberg H.: Drohobycz, Drohobycz. Warszawa 1997.

Jarzębski J.: Miasto Schulza. W: J. JarzęBski: Prowincja Centrum. Przypisy do Schulza. Kraków 2005.

Krynicka A.: Heterotopia Drohobycz. Dostępne w Internecie: http://www.nowakrytyka. pl/spip.php?article418 [data dostępu: 02.04.2016].

LaCapra D.: Trauma, nieobecność, utrata. Przeł. K. Bojarska. W: Antologia studiów nad traumą. Red. T. ŁysAK. Kraków 2015, s. 59-108.

Makuch J.: Od sztetla do Syjonu. „Tygodnik Powszechny” 2019, nr 1 (9): Polska żydowska (numer specjalny), s. 164-167.

Paziński P.: Rzeczywistość poprzecierana. Kraków-Budapeszt 2015.

Rewers E.: Post-polis. Wstęp do filozofii ponowoczesnego miasta. Kraków 2005.

Rewers E.: Wprowadzenie. W: Miasto w sztuce - sztuka miasta. Red. E. Rewers. Kraków 2010, s. 5-14.

SENdyka R.: Miejsca pamięci - lektury krytyczne. W: Od pamięci biodziedzicznej do postpamięci. Red. T. Szostek, R. Sendyka, R. Nycz. Warszawa 2013, s. 206-222.

SŁAwer T.: Miasto. Próba zrozumienia. W: Miasto w sztuce - sztuka miasta. Red. E. ReWERS. Kraków 2010, s. 17-69.

Walas T.: Literatura (kultura) jako selekcja i projektowanie doświadczenia. W: Kulturowa teoria literatury 2. Poetyki, problematyki, interpretacje. Red. T. Walas, R. Nycz. Kraków 2012, s. 273-310.

ZiĄTEK Z.: Czas literatury miejsca. W: Gry o tożsamość w czasach wielkiej zmiany. Red. A. Werner, T. Żukowski. Warszawa 2013, s. 127-149. 
Żadan S.: Drohobycz. Ksiega wierszy wybranych (2014-2016). Przeł. J. Podsiadeo. Warszawa 2018.

Agnieszka Czyżak

In the "Cities" of Drohobych: On Serhiy Zhadan's Volume of Poetry

Summary

The main aim of the article is to analyse the cultural phenomenon of Drohobych (now part of Ukraine), a small city where Bruno Schulz - a great European/Jewish/Polish writer - lived and died during the Second World War. The first part of this text contains reflections on literary visions of Drohobych (written by e.g. Andrzej Chciuk, Yurii Andrukhovych, Henryk Grynberg). In the second part of the article, the author proposes an interpretation of the volume of selected poems written in 2014-2016 by a Ukrainian poet Serhiy Zhadan and titled Drohobych (Drohobycz, translated into Polish by Jacek Podsiadło). All those writers treat Drohobych as "Bruno Schulz's place," full of his traces and created by his prose.

Key words: Drohobych, Zhadan, Holocaust, Schulz, contemporary poetry, memory 